\title{
Sanitser, an innovative sanitary ware body, formulated with waste glass and recycled materials
}

\section{(Sanitser, massa de louça sanitária inovadora,formulada com vidro e materiais reciclados)}

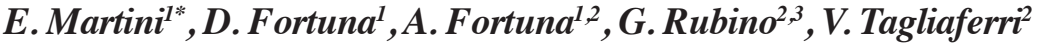 \\ ${ }^{1}$ SE.TE.C. Srl, via Enrico Fermi 6/18, 01033 Civita Castellana (VT), Italy \\ ${ }^{2}$ Department of Business Engineering, University of Rome "Tor Vergata", Via del Politecnico 1, 00133 Rome, Italy \\ ${ }^{3}$ Department of Economics and Business, University of Tuscia, Largo dell'Università, 01100 Viterbo, Italy \\ *laboratorio@setecsrl.it
}

\begin{abstract}
In the present paper, the results of "Sanitser" Life European project are presented. The aim of this study was to reduce the firing temperature for ceramic body (from 1250 to $1170{ }^{\circ} \mathrm{C}$ ). This was achieved substituting feldspar and quartz with recycled blend materials and a little percentage of flux (less than 3\%); in a sanitary ware vitreous china formulation a waste glass, granitic materials and fired broken ceramic pieces were introduced. Tests performed on the Sanitser formulation showed that it has the same final physical-chemical characteristics of the industrial vitreous china (VC) body. Besides, different ceramic pieces (wash basin, bidet and WC pan) were compared with VC production. The results showed that Sanitser body can replace vitreous china in the sanitary ware production. In this project, the firing temperature of the ceramic body is reduced significantly with a supposed decrease of the $\mathrm{CO}_{2}$ emissions. In Sanitser formulation, about $43.6 \%$ of recycled materials that would end in dumps were utilized.
\end{abstract}

Keywords: waste glass ceramic, porcelain, slip casting, thermal application.

\section{Resumo}

Neste artigo são apresentados os resultados do projeto europeu LIFE "Sanitser". Este trabalho teve como objetivo reduzir a temperatura de queima da massa cerâmica (de 1250 para $1170{ }^{\circ} \mathrm{C}$ ). Isto foi obtido substituindo a mistura de feldspato e quartzo por materiais reciclados e uma pequena percentagem de fundente (menos do que 3\%); em uma formulação de massa de sanitário vitrificado foram introduzidos resíduos de vidro, granito e materiais cerâmicos quebrados após queima. Os testes realizados mostraram que a formulação Sanitser apresenta as mesmas propriedades físicas e químicas da cerâmica vitrificada (VC). Além disso, várias peças de cerâmica (lavatório, bidê e vaso sanitário) foram comparadas com a produção de VC. Os resultados mostraram que a massa Sanitser pode substituir a massa VC na produção industrial. Neste projeto a temperatura de queima do corpo cerâmico é significativamente reduzida com a suposta redução das emissões de $\mathrm{CO}_{2}$. Na formulação Sanitser foram utilizados cerca de 43,6\% de materiais reciclados que acabariam em aterros sanitários.

Palavras-chave: resíduo de cerâmica vitrificada, porcelana, colagem de barbotina, aplicação térmica.

\section{INTRODUCTION}

The aim of this research was to replace total or partially the "hard" materials (feldspar and quartz), used for vitreous china (VC) sanitary ware slip, with recovery and recycled materials. The vitreous china bodies normally used in the sanitary ware casting [1-5], are in general a mix of clays (20-28\%), kaolin (25-35\%), quartz (17-31\%) and feldspar $(15-23 \%)$. The feldspar is a mixture of aluminium silicates of alkali and/or alkaline earth metals; the most important for the vitreous china sanitary ware industry are: i) orthoclase $\left(\mathrm{KAlOSi}_{3} \mathrm{O}_{8}\right)$ that is the main constituent of potassium feldspar; it has a very long melting range, gives a very viscous glaze and it has an incongruent melting around 1150 ${ }^{\circ} \mathrm{C}$; ii) albite $\left(\mathrm{NaAlSi}_{3} \mathrm{O}_{8}\right)$ that is the main constituent of sodium feldspar; it melts congruently at $1118{ }^{\circ} \mathrm{C}$ but has a shorter melting range and gives less viscous glass compared to potassium feldspar. Feldspars used in the industry are never pure but are a combination of the above-mentioned compounds to get the best compromise between viscosity, melting temperature, and melting range. In fact, the feldspar guarantees ending of vitrification process in the vitreous china pieces fired around $1250{ }^{\circ} \mathrm{C}[1,2,6,7]$. Quartz is a material of primary importance; it has an action on the sanitary ware bodies that can be summarised as follows: it corrects plasticity, being a non-plastic material, it reduces plasticity; it increases the whiteness of the finished product, given that it normally only contains small quantities of iron and/or titanium; it makes possible to vary the body's expansion coefficient; it increases the body's vitrification temperature; by its combination, in part with feldspathic glass, mullite is formed that, together with the residual 
quartz, makes up the framework of the ceramic body that restrict its deformation during firing $[1,2,6,7]$.

In Sanitser formulation a blend of waste glass, granite and broken fired VC pieces were inserted for replacement of the hard-raw materials (quartz and feldspar). Different concentrations of this mix were tested and at the end a sanitary ware body slip was produced. In this paper, the data obtained on the final formulation are shown. Previous researches, on the use of waste glasses in industrial products, have been published proving that such material can be an alternative to traditional constituents [8-12]. In particular, waste glass can replace feldspar, as reported in many papers in literature, in ceramic bodies [13-17]. Although from the literature [18-20] it is obvious that for ceramics formed by slip casting the presence of glass causes problems on stabilizing the cast slip, in this study these problems were overcame with proper measurements. In fact, in sanitary ware process the VC body must respect a series of parameters, in particular: guarantee right rheological properties to permits the casting (Gallenkamp viscosity of around $300-330{ }^{\circ} \mathrm{G}$, thixotropy after $1 \mathrm{~min}$ of around $20-30{ }^{\circ} \mathrm{G}$, and thickness after $1 \mathrm{~h}$ of at least $7 \mathrm{~mm}$ ); have a flexural resistance above $2 \mathrm{MPa}$ in raw pieces, and above $40 \mathrm{MPa}$ in final products to avoid breakages during, respectively, the handling and the use; present a final shrinkage less than $12 \%$ to preserve original piece design; be in dilatometric according with the glaze to avoid defects like crazing and peeling; and have final water absorption less than $0.5 \%$ to guarantee hygiene during the product life. In our formulation, all these parameters were verified and compared to the values of standard vitreous china. Using the Sanitser, body was produced by the forming process of sanitary ware, in a pilot plant, without changing the process steps of the traditional casting [1, 2, 21-23]. Obviously, sanitary ware products must respect several boundaries to guarantee safety, hygiene and aesthetic properties. Therefore, the sanitary ware pieces, produced in Sanitser project, were tested in compliance to European and Italian standards, in particular EN 997, EN 14528 and EN 14688 that allow the CE marking, and UNI 4543. The latter describes the test methods adopted for verify chemical and physical resistance of the ceramic mass and glaze [24-27].

\section{EXPERIMENTAL}

Raw materials: Hycast Rapide ball clay, Hycast VC ball clay, flux, Remblend kaolin (Imerys Ceramics, Italy); Sanblend 90 ball clay, HPC kaolin and CC31 kaolin (Sibelco, Italy); Imperial kaolin (Sedlecky Caolin, Turkey); BB-Z kaolin, ceramic blend composed of glass filler GS-VF, pitcher BVC-VF, and F60-PBVF (Minerali Industriali, Italy). In Table I the technical data of the recycled materials, insert in the mix, are shown. The waste glass GS-VF comes from glass bottle, the pitcher BVC-VF comes from recovery of sanitary ware ceramics production and F60-PBVF is the recovery of the Verbania historical white granite quarries.
Table I - Average chemical composition (wt\%) and granulometric parameter of recycled materials, insert in blend formulation, used in Sanitser body.

[Tabela I - Composição química média (\% em massa) $e$ parâmetro granulométrico de materiais reciclados adicionados na formulação da mistura usada no corpo de Sanitser.]

\begin{tabular}{cccc}
\hline Oxide & $\begin{array}{c}\text { Glass filler } \\
\text { GS-VF }\end{array}$ & $\begin{array}{c}\text { Granite } \\
\text { F60-PBVF }\end{array}$ & $\begin{array}{c}\text { Pitcher } \\
\text { BVC-VF }\end{array}$ \\
\hline $\mathrm{SiO}_{2}$ & 71.7 & 77.10 & 70.80 \\
$\mathrm{Al}_{2} \mathrm{O}_{3}$ & 2.70 & 13.00 & 22.00 \\
$\mathrm{Fe}_{2} \mathrm{O}_{3}$ & 0.42 & 0.10 & 0.60 \\
$\mathrm{TiO}_{2}$ & 0.07 & 0.02 & 0.40 \\
$\mathrm{CaO}$ & 9.50 & 1.10 & 0.70 \\
$\mathrm{MgO}$ & 2.00 & 0.08 & 0.25 \\
$\mathrm{~K}_{2} \mathrm{O}$ & 1.00 & 4.70 & 1.40 \\
$\mathrm{Na}_{2} \mathrm{O}$ & 12.50 & 3.40 & 3.60 \\
L.O.I. & 0.10 & 0.30 & 0.25 \\
Retained on & $2 \%$ & $2 \%$ & $<3 \%$ \\
$75 \mu \mathrm{m}$ sieve & & & \\
\hline
\end{tabular}

Vitreous china formulations: the casting slip Sanitser was formulated and prepared in laboratory and in pilot plant of the SE.TE.C., using the raw materials cited above, while the standard vitreous china slip, used for a comparison, came from a sanitary ware factory. In Table II the compositions for both slips are shown. The percentage of the raw materials recycled in Sanitser body was about of $43.6 \%$ of the dry weight of the body.

Equipments for laboratory tests: universal torsion viscometer (mod. TV/30/A, Gallenkamp type), stove thermostat, bending test machine (mod. Mor/1), electronic balances (BE/95 series) (Ceramics Instruments, Italy); electric gradient kiln, electronic calliper (Gabbrielli, Italy); gypsum mould and laboratory mixer (SE.TE.C., Italy), electronic dilatometer (DIL 402, Netzsch-Gerätebau, Germany), heating microscope (Misura HSM/HSML, TA Instruments, USA).

Table II - Sanitary ware body compositions.

[Tabela II - Composições de massas de louça sanitária.]

\begin{tabular}{ccc}
\hline Raw material & $\begin{array}{c}\text { Sanitser } \\
\text { body }\end{array}$ & $\begin{array}{c}\text { Conventional } \\
\text { vitreous china }\end{array}$ \\
\hline Ball clays & $24.0 \%$ & $24.0 \%$ \\
Kaolins & $30.0 \%$ & $29.5 \%$ \\
Ceramic blend & & - \\
(waste glass 9.5\% & $43.62 \%$ & \\
+granite +pitcher) & & \\
Quartz & - & $27.50 \%$ \\
Feldspars & - & $19.00 \%$ \\
Fluxes & $2.38 \%$ & - \\
\hline
\end{tabular}


Preparation of Sanitser slurry: equipments used in pilot plant for production of sanitary ware were: turboblunger of $1 \mathrm{~m}^{3}$ ( $1^{\text {st }}$ step $)$, turboblunger of $0.5 \mathrm{~m}^{3}\left(2^{\text {nd }}\right.$ step $)$, vibrating sieve with de-ironing $\left(1^{\text {st }}\right.$ and $2^{\text {nd }}$ steps), tank with slow agitator ( $1^{\text {st }}$ and $2^{\text {nd }}$ steps $)$, casting bench, intermittent dryer, glazing plant, and kiln $\left(1 \mathrm{~m}^{3}\right)$. Tests were performed with the two compositions (Table II). In Sanitser slurry, the raw materials and water were mixed as in the production cycle normally used in VC sanitary ware industry. To prepare the slips, the following main steps were used: 1) dispensing of raw materials, and dispersing clays, glass filler GS-VF and water $\left(1^{\text {st }}\right.$ step) inside the mixers or turbine mixers of $1^{\text {st }}$ step; 2) sieving and deferrization of the fraction obtained; 3) mixing the clayey suspension with kaolins, pitcher BVCVF, talc, granite F60-PBVF ( $2^{\text {nd }}$ step), again inside the turbine mixers of $2^{\text {nd }}$ step; 4) sieving and deferrization of the body obtained; 5) maturing of slip inside slow propellermixers. The VC body was stored in wells equipped with slow mixers until it was sent via pumps to the central casting tubes to serve single machines or manual casters. Viscosity, thixotropy of the slip at $1 \mathrm{~min}$ and litre weight were checked on the slip preparations after ageing. To get better dispersion $0.5 \%$ sodium silicate was added to the slurry before mixing. In Sanitser body, this deflocculant was not added in the first step.

Equipments for pre-industrial tests: sanitary ware manufacturing process consisted of different stages from body preparation to firing. They were: body preparation (described above); glaze preparation; moulding/mould preparation; casting; drying; control and spraying; and firing.

Sanitser characterization in laboratory: the characterizations of the slips were made according to the method adopted in the sanitary ware industry. The Sanitser body was cast into plaster mould at room temperature to prepare a series of samples necessary to measure some physical parameters of the dry and fired slip: 1) rheological test: a liquid slip was prepared to measure its viscosity and thixotropy after 1 min by a Gallenkamp viscometer; 2) thickness formation and consolidation test: the slip was cast in a gypsum cup, a drain type mould, in which the excess of the slip was drained away after $1 \mathrm{~h}$; after about 30 min, thickness of the body formed on the cup's wall and humidity of the piece were measured; 3 ) modulus of rupture (MOR), i.e. 3-point flexural testing: 10 rectangular bars were prepared, casting slip in a plaster mould with dimensions of $150 \mathrm{~mm}$ x $30 \mathrm{~mm}$ x $20 \mathrm{~mm}$; after $1.5 \mathrm{~h}$, excess of slip was poured away from the mould; the samples were removed from the mould and allowed to dry at $40{ }^{\circ} \mathrm{C}$ for 1 day in a stove; the strength of the specimens was measured using a bending test machine; 3) linear firing shrinkage: 3 rectangular bars were prepared casting the slip in a plaster mould with dimensions of $200 \mathrm{~mm}$ x $30 \mathrm{~mm}$ x $20 \mathrm{~mm}$; after $2 \mathrm{~h}$ the excess of slip was poured away from the mould, and samples were allowed to dry in stove at $40{ }^{\circ} \mathrm{C}$ for 1 day; the green specimens were fired at $1165-1170{ }^{\circ} \mathrm{C}$ in a laboratory gradient kiln. Following ASTM C326-82 [28] and UNI 4543 [27], the linear shrinkage was calculated by the equation: $\mathrm{LS} \%=(\mathrm{Ls}-\mathrm{Lc}) / \mathrm{Ls} \times 100$; being Ls and Lc the length $(\mathrm{mm})$ of the green and fired specimens, respectively; 5) water absorption: it was determined via boiling the fired sample in distilled water for $2 \mathrm{~h}$ and by immersing in water for 1 day; then the specimens were removed from water, dried with a cotton cloth then weighed; it was calculated following ASTM C373-88 [29], EN 997 [24] and UNI 4543 [27] standards; in these methods, samples are exposed to saturation of water, achieved by boiling or vacuum, depending on the method.

At this point, it was necessary, before switching to the pre-industrial stage of sanitary ware casting, to analyse the behaviour of the body in the firing process and its dilatometric agreement with the glaze. A dilatometric analysis of the fired pieces was performed, while on the dry slip was carried out a vitrification curve by a heating microscope. The slip powder sintering in air was monitored by an optical heating microscope (Misura ODHT-HSM, Expert System Solutions, Italy) at $10{ }^{\circ} \mathrm{C} / \mathrm{min}$ in the range of about $900-1300{ }^{\circ} \mathrm{C}$. At the end, a quantitative $\mathrm{X}$-ray diffraction (XRD) was carried out. This is a typical technique for routine quality control of powders and materials discovery. Quantitative XRD (D5000, Siemens AG, Germany) and full structure refinement were used to characterize Sanitser body slip at different temperatures in order to verify the phase composition.

Pre-industrial tests - body preparation and casting process: at this stage in the pilot plant it was proceeded to the body preparation and the casting of a series of articles, basins and WC pans. The casting process permitted to identify how the Sanitser body slip behaved with different shapes and different geometries. Furthermore, deformations and defects that may be encountered on the specific pieces can be analysed. The pieces were produced according to the process described above, in which the plaster moulds of different wash basin models and WC pans were assembled in automatic benches for casting.

\section{RESULTS AND DISCUSSION}

Rheological test: this test allows to simulate the production conditions and so to evaluate body castability and its deflocculants requested of the body. As shown in Table III, Sanitser body slip did not need deflocculant as sodium silicate. It is due to the introduction of recycled glass material. As reported [18-20], the waste glass introduction in ceramic formulation has an alkalinizing effect (change $\mathrm{pH}$ ). Using waste glass, the release of the sodium and calcium ions to form their respective hydroxides are expected [1820]. Indeed, this release results in a deflocculant action; in fact, this caused the viscosity and thixotropy decrease. The deflocculating effect of glass is similar to sodium silicate. Therefore, the body preparation procedure was changed, adding the glass directly in the first step without sodium silicate. Only a small percentage of polyacrylate deflocculant (about $0.08 \% \mathrm{w} / \mathrm{w}$ ) was used in $2^{\text {nd }}$ step. Furthermore, the thickness formation after $60 \mathrm{~min}$ was the same of the vitreous china and this confirmed the Sanitser castability. 
Table III - Characteristic data obtained from Sanitser slip compared with industrial vitreous china slip (each value is the mean of five determinations).

[Tabela III - Características da barbotina de Sanitser comparadas com a barbotina de porcelana vítrea industrial (cada valor é média de cinco determinações).]

\begin{tabular}{lcc}
\hline Technical parameter & $\begin{array}{c}\text { Industrial } \\
\text { slip (RSD } \\
\leq 5.0 \%)\end{array}$ & $\begin{array}{c}\text { Sanitser } \\
\text { slip (RSD } \\
\leq 5.0 \%)\end{array}$ \\
\hline Density $\left(\mathrm{g} / \mathrm{cm}^{3}\right)$ & 1.800 & 1.800 \\
Moisture $(\%)$ & $32-35$ & 34.3 \\
Viscosity $\left({ }^{\circ} \mathrm{G}\right)$ & 305 & 295 \\
Sodium silicate deflocculant $(\%)$ & 0.17 & - \\
Sodium carbonate deflocculant $(\%)$ & 0.07 & 0.07 \\
Polyacrylate deflocculant $(\%)$ & - & 0.05 \\
Thixotropy after 1 min $\left({ }^{\circ} \mathrm{G}\right)$ & $25-35$ & 30 \\
Deformation $(\mathrm{mm})$ & $40-43$ & 43 \\
Thickness after $1 \mathrm{~h}(\mathrm{~mm})$ & $6.5-7.0$ & 6.6 \\
Modulus of rupture $\left(\mathrm{kgf} / \mathrm{cm}^{2}\right)$ & $24-25$ & 25.3 \\
Flexural strength after firing ${ }^{1}(\mathrm{MPa})$ & $49.5^{\mathrm{a}}$ & $55.7^{\mathrm{b}}$ \\
Linear firing shrinkage $(\%)$ & $12-13^{\mathrm{a}}$ & $12.6^{\mathrm{b}}$ \\
Water absorption $(\%)$ & $<0.5^{\mathrm{a}}$ & $0.1^{\mathrm{b}}$ \\
\hline
\end{tabular}

Notes: $R S D$ - relative standard deviation; ${ }^{1}$ - UNI 4543 requires a value $>39.50 \mathrm{MPa} ;{ }^{2}-$ EN 997 and UNI 4543 require a value $<0.5 \%{ }^{a}{ }^{-}$- fired at $1250{ }^{\circ} \mathrm{C} ;{ }^{b}$ - fired at $1165^{\circ} \mathrm{C}$.

Flexural test: this test allows an evaluation of mechanical properties for both raw and fired pieces. The raw flexural strength is important during industrial production because it allows to avoid abrupt brakeage due to handling and fissuring during the drying cycle caused by moisture gradients. For these reasons, high raw mechanical strength means reducing scraps and thus improving productivity [30, 31]. Instead, the fired flexural resistance, according to standards EN 14688, EN 14528 and EN 997, is important because it guarantees safety condition during the product life cycle. Indeed, an abrupt piece breakage could be very dangerous. As shown in Table III, the results were very good for both raw and fired samples. Therefore, the Sanitser formulation is in accordance with the standards [24-26].

Linear shrinkage: it allows to evaluate the sintering behaviour of the fired samples and the final product dimension $[28,32]$. Normally in the VC pieces, final shrinkage lower than $12 \%$ is accepted. Indeed, higher values would mean unacceptable deformation.

Water absorption: low values of water adsorption or porosity suggest a high degree of vitrification [29, 33]. Moreover, low water absorption $(<0.5 \%)$ is fundamental to guarantees hygiene during the product life cycle, in particular for WC pans. So, tests according to standards EN 997 and UNI 4543 were carried out $[24,27]$. As shown in Table III, also in this case, the Sanitser formulation was very similar to a vitreous china body.

The rheological parameters (as viscosity, thixotropy and density) of Sanitser slip had characteristic values in line with the ranges found for VC body, adding water or deflocculants. Also, deformation, thickness, linear shrinkage, water absorption and MOR values fall within the ranges reported for VC body. Regarding the mechanical properties, the average bending strength of samples VC fired at $1230-1250^{\circ} \mathrm{C}$ range is $>39.5 \pm 2 \mathrm{MPa}$, prescribed in the standard UNI 4543 for these ceramic materials. Meanwhile for Sanitser body fired at 1165 ${ }^{\circ} \mathrm{C}$ this value increased about $12 \%$. The Sanitser body showed better mechanical characteristics probably due to enhanced microstructural homogeneity, as reported in literature for porcelain in which the waste glass was added [34, 14].

Vitrification curve: the best vitrification temperature range is achieved when open porosity reaches a minimum value, nearly zero, and simultaneously linear shrinkage is maximum. Firing above vitrification temperature range results in a drastic fall of the physical properties due to forced expulsion of the entrapped gases, resulting in blisters and bloating [33, 35]. Fig. 1 shows vitrification curve, in which the linear shrinkage and the water absorption are plotted as a function of different firing temperature for Sanitser body. This test allowed to prove that for Sanitser body the optimum firing temperature is in the $1160-1180{ }^{\circ} \mathrm{C}$ range. It is clear that linear shrinkage increases as the sintering temperature increase, and in this range, it is lower in the sample sintered at $1170^{\circ} \mathrm{C}$. In vitreous ceramic body, the best range of linear shrinkage is about 12$13 \%$ and this range was satisfied for Sanitser slip fired at 1145$1175^{\circ} \mathrm{C}$. During sintering process, porosity of ceramic body is reduced. So, the shrinkage is related to the pores removed or lost. Sintering temperature has an extreme effect on the value of linear shrinkage as increasing sintering temperature leads to higher linear shrinkage due to increasing amount of molten material filling the pores. Continuing to increase sintering temperature to $1180^{\circ} \mathrm{C}$, sintering continues resulting in lower porosity and higher shrinkage.

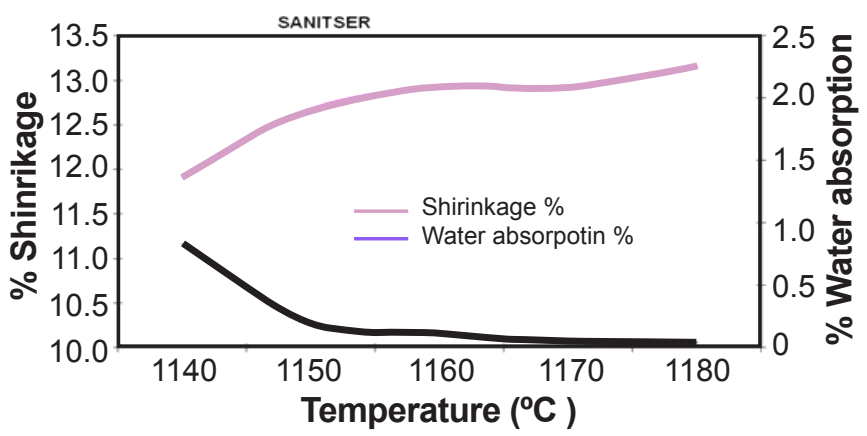

Figure 1: Linear shrinkage and water absorption as a function of firing temperature for Sanitser sample.

[Figura 1: Retração linear e absorção de água em função da temperatura de queima para amostra de Sanitser.]

Dilatometric behaviour: it is also used to check the progress of chemical reactions, particularly those displaying a large molar volume change, as the rate of phase changes $[1,2,36,37]$. Another common application of a dilatometer 
Table IV - Dilatometric coefficients, $\alpha\left(\mathrm{K}^{-1}\right)$, obtained from slips of Sanitser and industrial standard vitreous china.

[Tabela IV - Coeficientes dilatométricos, $\alpha\left(K^{-1}\right)$, obtidos das massas de Sanitser e porcelana vítrea industrial de referência.]

\begin{tabular}{ccc}
\hline $\begin{array}{c}\text { Temperature } \\
\text { range }\left({ }^{\circ} \mathrm{C}\right)\end{array}$ & $\begin{array}{c}\text { Vitreous china } \\
\text { standard }\end{array}$ & Sanitser body \\
\hline $50-200$ & $65.6 \times 10^{-7}$ & $67.8 \times 10^{-7}$ \\
$50-300$ & $64.5 \times 10^{-7}$ & $68.9 \times 10^{-7}$ \\
$50-400$ & $65.5 \times 10^{-7}$ & $69.8 \times 10^{-7}$ \\
$50-500$ & $66.7 \times 10^{-7}$ & $70.7 \times 10^{-7}$ \\
$50-650$ & $71.2 \times 10^{-7}$ & $74.1 \times 10^{-7}$ \\
$300-500$ & $69.5 \times 10^{-7}$ & $72.9 \times 10^{-7}$ \\
$500-650$ & $84.6 \times 10^{-7}$ & $84.3 \times 10^{-7}$ \\
\hline
\end{tabular}

is the measurement of thermal expansion. The dilatometer allows recording material's expansion and contraction by using a contact method $[1,2,36,37]$ in compliance with ASTM E228-11 [38]. In Table IV, coefficients of expansion, $\alpha$, for both slips are shown. Sanitser formulation had values compatibles with conventional sanitary ware bodies.

Heating microscope: this analysis allows photographing the firing body behaviour during heating [39-42]. As shown in Fig. 2, Sanitser formulation presented a firing curve shifted towards lower temperatures, with a greater slope between 1110 and $1250^{\circ} \mathrm{C}$. After $1250{ }^{\circ} \mathrm{C}$ the Sanitser slip showed a trend entirely different from that of the body of VC standard. This behaviour was due to the glass effects in the mullite formation [43] and over $1250{ }^{\circ} \mathrm{C}$ it is possible to see an expansion of the sample certainly due to forming gases. This analysis allowed to confirm that Sanitser formulation has a low firing behaviour.

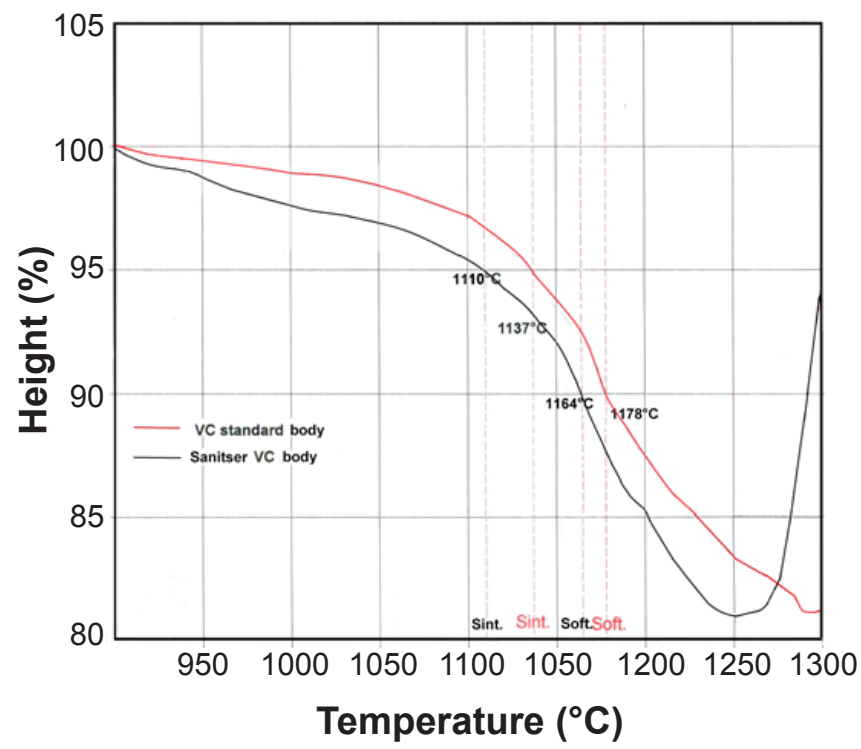

Figure 2: Firing behaviour for Sanitser body compared with standard $\mathrm{VC}$ by heating microscope.

[Figura 2: Comportamento de queima do corpo Sanitser comparado com o VC de referência por microscópio de aquecimento.]
XRPD (X-ray powder diffraction) analysis: it has been reported that the formation of mullite in ceramics occurs at lower temperatures when the waste glass is added [43-46]. Therefore, the formation of crystalline phases in Sanitser body through XRPD analysis was verified. This allowed to confirm the formation of mullite by the Rietveld method [4346]. Mullite was synthesized by firing the starting material (Sanitser body) at various temperatures. By this method, it was possible to determine quantitatively the amounts of crystalline phases and the remaining amorphous phase. The major phase present after firing was the vitreous phase (from $58 \%$ to $63 \%$ ). The major crystalline phases were quartz (14$18 \%)$ and mullite (11-18\%). Minor amounts of feldspar (plagioclase) and cristobalite were also present (Fig. 3). The Sanitser body has a comparable ratio between crystalline phases and amorphous phase, at lower temperatures of about $80{ }^{\circ} \mathrm{C}$ than the traditional vitreous china. This ratio, between amorphous and crystalline component, remains almost constant in the entire temperature range explored. This suggested that transformations occurred in the body at temperatures slightly higher than $1110{ }^{\circ} \mathrm{C}$. A detailed analysis of phases showed, in fact, that their contents unchanged from 1120 to $1180{ }^{\circ} \mathrm{C}$, except for an increase of mullite and a decrease of other crystalline phases at high temperatures (above $1200{ }^{\circ} \mathrm{C}$ ).

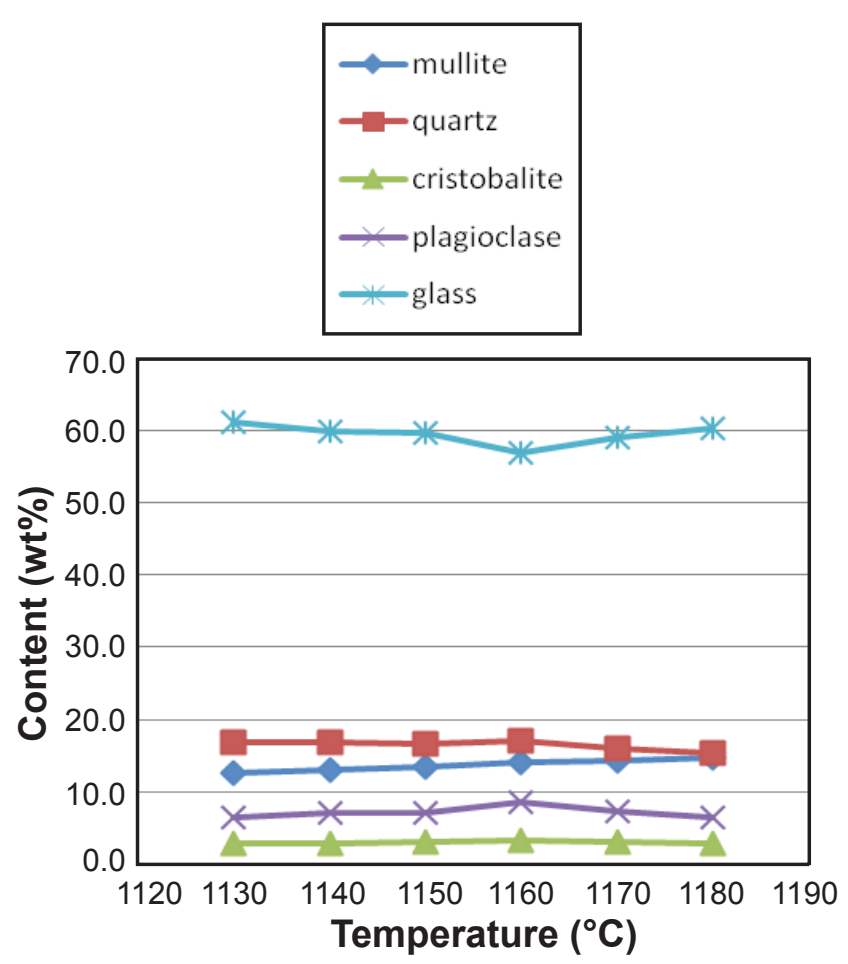

Figure 3: Crystalline phase analysis for Sanitser body (VC) at different temperatures.

[Figura 3: Análise das fases cristalinas para o corpo de Sanitser (VC) nas diferentes temperaturas.]

Pre-industrial test: this is the most important test because it reproduces production conditions and makes 
possible a comparison between Sanitser formulation and vitreous china. To carry out these trials, about 60 real pieces (wash basin, WC pans and bidet) were casted, glazed and fired, maintaining the same working time and rheological conditions used in factory. All cast pieces were sprayed using a low firing glaze, developed specifically for this project, and fired at $1170{ }^{\circ} \mathrm{C}$. The kiln present in the pilot plant, according to the type of heating system adopted, was a gaseous shuttle kiln. The firing curve used for the Sanitser slip took around $17 \mathrm{~h}$ (Fig. 4), shorter than an industrial cycle that has a duration of about 19-22 $\mathrm{h}$. The lower firing temperature and the shorter firing cycle have confirmed that if the Sanitser slip is used in the industry, this can result in a significant decrease in $\mathrm{CO}_{2}$ generation and the energy required to fire the sanitary wares.

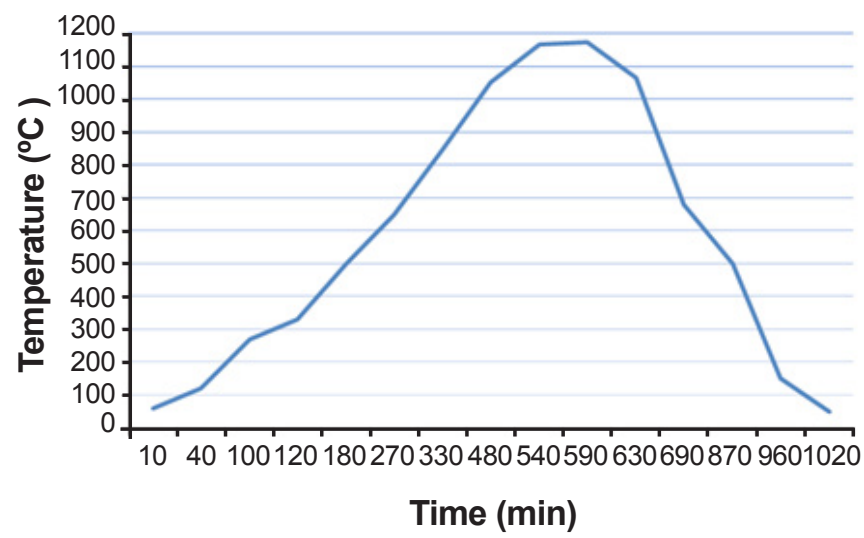

Figure 4: Firing curve used for Sanitser pieces.

[Figura 4: Curva de queima usada pelas peças de Sanitser.]

Fig. 5 shows several sanitary ware products obtained in the Sanitser project. In pre-industrial production, no differences were observed in relation to vitreous china pieces. Indeed, Sanitser raw and fired scraps are comparable to those of vitreous china. Furthermore, it is important to

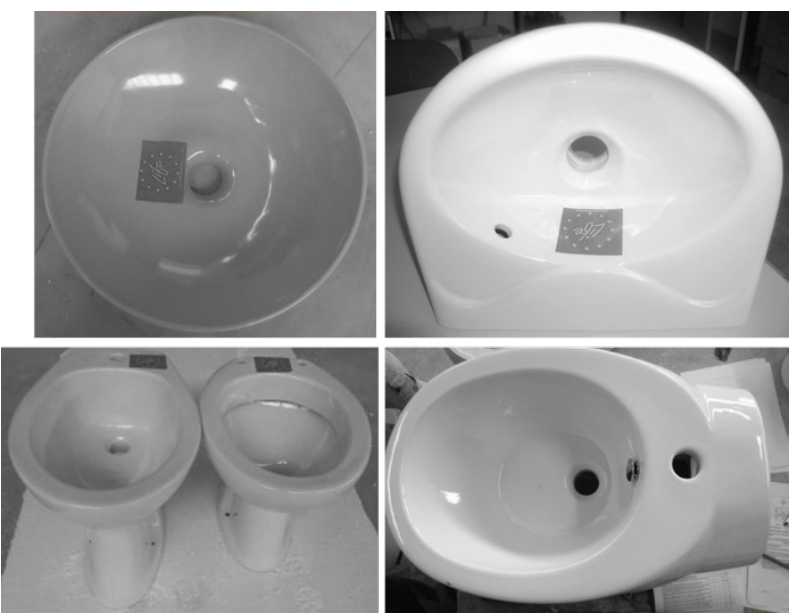

Figure 5: Wash basins, WC pans and bidets produced with Sanitser body.

[Figura 5: Cubas, bacias e bidês sanitários produzidos com a massa de Sanitser.] underline that different shapes were prepared to demonstrate the Sanitser castability.

\section{CONCLUSIONS}

In this paper, the results of Sanitser Life project were summarized and the possibility to decrease the firing temperature of vitreous china (VC) bodies from 1250 to $1170{ }^{\circ} \mathrm{C}$ was proved. For this, the feldspar and quartz were substituted by a recycled blend (waste glass, granite and pitcher) in a fraction of about $43.6 \mathrm{wt} \%$ of the total formulation. To confirm this, several trials were made, which allowed to compare Sanitser formulation with a standard VC body. All tests confirmed that it is possible to decrease the firing temperature without jeopardizing properties normally wanted in sanitary ware. Indeed, there are no significant differences in rheological and mechanical properties, shrinkage and water absorption. Sanitser slip and the pieces produced with it overcome the requirements of EN standards and satisfy industrial parameters. Besides, preindustrial trials confirmed good results obtained and the next steps involve the industrialization of the Sanitser slip. The novelty of this research is not the waste glass insertion in ceramic formulations, as today it is used especially in the tile industry, but for the first time the rheological problems were overcame despite the high percentage of waste glass used, which was $9.5 \%$. Also for the first time in a VC body, the hard-raw materials (quartz and feldspar) were replaced by recycled materials with low contents of free silica. This allowed to obtain a ceramic body less dangerous to the workers' health. Finally, at technological level the possibility to fire the VC body at a lower temperature of about $80^{\circ} \mathrm{C}$, can allow an energy saving and a consequent reduction in $\mathrm{CO}_{2}$ emissions.

\section{ACKNOWLEDGMENTS}

Authors are indebted to SE.TE.C. srl (Civita Castellana, Italy) for advice on the ceramic bodies formulation, and Minerali Industriali srl which supplied materials for vitreous china formulations.

\section{REFERENCES}

[1] D. Fortuna, Sanitaryware, Faenza Editrice, Faenza (2000).

[2] D. Fortuna, Sanitaryware casting, SE.TE.C. srl Editorial, Civita Castellana (2011).

[3] G. Aliprandi, Principi di ceramurgia e tecnologia ceramica, $2^{\text {nd }}$ ed., E.C.I.G, Genova (1975).

[4] G. Peco, I prodotti ceramici: dalla tradizione all'alta tecnologia, Marzorati Editore, Milan (1991).

[5] W.D. Kingery, H.K. Bowen, D.R. Uhlmann, Introduction to ceramics, John Wiley \& Sons, New York (1975).

[6] G.W. Phelps, "Ceramics monographs - a handbook of ceramics", Verlag Schmidt, Freiburg i. Brg., Germany (1982). 
[7] R. Herrmann, "Ceramics monographs - a handbook of ceramics", Verlag Schmidt, Freiburg i. Brg., Germany (1989).

[8] W. Pannhorst, in: Low thermal expansion glass ceramics, H. Bach (Ed.), Springer, Germany (1995) 1.

[9] J.M. Rincon, M. Romero, Materiales Construcción 46, 242-243 (1996) 91.

[10] S. Fotiadou, M.C. Limbachiya, A.N. Fried, J.J. Roberts, in: Sustainable waste management and recycling: glass waste, M.C. Limbachiya, J. Roberts (Eds.), Thomas Telford, London (2004) 305.

[11] R. Siikamaki, L. Hupa, in: Recycling and reuse of glass cullet, R. Dhir, M.C Limbachiya, T.D. Dyer (Eds.), Thomas Telford, London (2001) 135.

[12] S.R. Bragança, C.P. Bergmann, in: Sustainable waste management and recycling: glass waste, M.C. Limbachiya, J. Roberts (Eds.), Thomas Telford, London (2004) 217.

[13] S.R. Bragança, C.P. Bergmann, Mat. Res. 8, 1 (2005) 39.

[14] A. Tucci, L. Esposito, E. Rastelli, C. Palmonari, E. Rambaldi, J. Eur. Ceram. Soc. 24, 1 (2004) 83.

[15] F. Matteucci, M. Dondi, G. Guarini, Ceram. Int. 28, 8 (2002) 873.

[16] A.P. Luz, S. Ribeiro, Ceram. Int. 33, 5 (2007) 761.

[17] N.F. Youssef, M.F. Abadir, M.A.O. Shater, J. Eur. Ceram. Soc. 18, 12 (1998) 1721.

[18] S.R. Bragança, R. Camaratta, A.C. Taborda, C.P. Bergmann, Mater. Sci. Forum 530-531 (2006) 449.

[19] L.A. Carús, L. Bento, S.R. Bragança, Cerâmica 60 (2014) 164.

[20] S.R. Bragança, C.P. Bergmann, Int. J. Ceram. Technol. 6, 2 (2009) 264.

[21] R. Herrmann, "Slip casting in practice, ceramics monographs - handbook of ceramics", Verlag Schimdt, Freiburg i. Brg, Germany (1989).

[22] J.S. Reed, Principles of ceramics processing, $2^{\text {nd }}$ ed., John Wiley \& Sons, New York (1998).

[23] C.H. Schilling, I.A. Aksay, in: Engineered materials handbook ASTM, Ceramics and glasses handbook (1991) 153.

[24] UNI EN 997:2015, "Vasi indipendenti e vasi abbinati a cassetta, con sifone integrato", ICS [91.140.70], UNI, Milano, Italy.

[25] UNI EN 14528:2015, "Bidè - requisiti funzionali e metodi di prova", ICS [91.140.70], UNI, Milano, Italy.

[26] UNI EN 14688:2015 "Apparecchi sanitari - lavabi requisiti funzionali e metodi di prova”, ICS [91.140.70],
UNI, Milano, Italy.

[27] UNI 4543-2:1986, "Ceramic Sanitary Appliances - Tests On Ceramic Materials", ICS [91.140.70], UNI, Milano, Italy.

[28] ASTM C 326-82 (reapproved 1988), "Standard test method for drying and firing shrinkage of ceramic white ware clays", ASTM Int., West Conshohocken (1988).

[29] ASTM C 373-88, "Standard test method for water absorption, bulk density, apparent porosity and apparent specific gravity of fired white ware products", ASTM Int., West Conshohocken (1988).

[30] G. Sthatis, A. Ekonomakou, C.J. Stournaras, C. Ftikos, J. Eur. Ceram. Soc. 24 (2004) 2357.

[31] L. Barbieri, L. Bonfatti, A.M. Ferrari, C. Leonelli, T. Manfredini, D. Settembre Blundo, in: Ceramics: charting the future, P. Vincenzini (Ed.), Vol. 3A, Techna Srl, Modena (1995) 99.

[32] S. Parveen, S.A. Jahan, Bangladesh J. Sci. Ind. Res. 45, 4 (2010) 387.

[33] A. Bernasconi, V. Diella, A. Pagani, A. Pavese, F. Francescon, K. Young, J. Stuart, L. Tunnicliffe, J. Eur. Ceram. Soc. 31 (2011) 1353.

[34] W.D. Kingery, J. Amer. Ceram. Soc. 38, 1 (1955) 3.

[35] J. Martín-Márquez, J.M. Rincón, M. Romero, Ceram. Int. 34 (2008) 1867.

[36] M. Vokáč, A. Kloužková, V. Hanykýř, P. Bouška, Ceramics - Silikáty 53, 4 (2009) 303.

[37] M. Paganelli, "The non-contact optical dilatometer designed for the behaviour of ceramic raw materials", Expert System Solutions S.r.l., Modena, Italy.

[38] ASTM E228-11, "Standard test method for linear thermal expansion of solid materials with a push-rod dilatometer", ASTM Int., West Conshohocken (2011),

[39] C. Siligardi, M.C.D'Arrigo, C. Leonelli, Am. Ceram. Soc. Bull. 79, 9 (2000) 88.

[40] M. Paganelli, Ceram. World Rev. 24, 97 (1997) 148.

[41] M. Paganelli, Ind. Ceram. 17, 2 (1997) 69.

[42] M. Paganelli, Ceramurgia 4 (1997) 232.

[43] N. Marinoni, D. D’Alessio, V. Diella, A. Pavese, F. Francescon, J. Environ. Manag. 124 (2013) 100.

[44] L. Lutterotti, R. Ceccato, R. Dal Maschio, E. Pagani, Materials Sci. Forum 278-281 (1998) 87.

[45] A. Bernasconi, V. Diella, A. Pagani, A. Pavese, F. Francescon, K. Young, J. Stuart, L. Tunnicliffe, J. Eur. Ceram. Soc. 31 (2011) 1353.

[46] K. Yasukawa, Y. Terashi, A. Nakayama, J. Am. Ceram. Soc. 81, 11 (1998) 2978.

(Rec. 16/01/2017, Rev. 20/02/2017, Ac. 01/03/2017) 